\title{
Cow dung: a potential biomass substrate for the production of detergent-stable dehairing protease by alkaliphilic Bacillus subtilis strain VV
}

\author{
Ponnuswamy Vijayaraghavan ${ }^{1 *}$, Aija Vijayan², Arumugaperumal Arun³, John Kennady Jenisha ${ }^{3}$ \\ and Samuel Gnana Prakash Vincent ${ }^{1}$
}

\begin{abstract}
Cow dung, a cheap and easily available source of energy, was used as the substrate for the production of alkaline protease by solid-state fermentation using the Bacillus subtilis strain W. In order to achieve the maximum yield of this enzyme, the following optimum process parameters are needed: fermentation period (72 h), $\mathrm{pH}(10.0)$, moisture content $(140 \%)$, inoculum $(25 \%)$, temperature $\left(30-40^{\circ} \mathrm{C}\right)$, carbon source $(2 \%(\mathrm{w} / \mathrm{w})$ maltose) and nitrogen source $\left(1 \%(\mathrm{w} / \mathrm{w})\right.$ urea). The protease was stable over a broad temperature range $\left(30-50^{\circ} \mathrm{C}\right)$ and $\mathrm{pH}(8.0-10.0)$, with maximum activity at $50^{\circ} \mathrm{C}$ and $\mathrm{pH}$ 10.0. Among the divalent ions tested, $\mathrm{Ca}^{2+}(0.01 \mathrm{M})$ increased enzyme activity. The purified protease, after being subjected to sodium dodecyl sulphate-polyacrylamide gel electrophoresis, was found to have a molecular mass of $38.5 \mathrm{kDa}$. The enzyme was solvent-and surfactant-stable and showed activity even after $24 \mathrm{~h}$ incubation along with various commercially available detergents. This enzyme possessed dehairing properties for animal hide after $16 \mathrm{~h}$ of incubation at room temperature. From these results it is evident that cow dung is a potential substrate for the production of a detergent-stable, dehairing protease by $B$. subtilis. This enzyme has a lot of potential applications in the detergent and leather-processing industries.
\end{abstract}

Keywords: Cow dung, Solid-state fermentation, Bacillus subtilis strain W, Alkaline protease, Detergent-stable

\section{Background}

Proteases constitute one of the commercially important groups of extra-cellular microbial enzymes and are widely used in the detergent, food, pharmaceutical, chemical and leather industries (Scheuer 1990). These enzymes account for $40 \%$ of the total enzyme sales worldwide and this trend is expected to increase in the near future. This has led to increasing attention towards the exploitation of potent microbial strains for the production of alkaline proteases from an industrial point of view (Ellaiah et al. 2002). Although a wide range of microorganisms are known to produce proteases, a large proportion of the commercially available form of these enzymes is derived from Bacillus strains because of their ability to secrete large amounts of alkaline proteases

\footnotetext{
* Correspondence: venzymes@gmail.com

'International Centre for Nanobiotechnology, Centre for Marine Science and Technology, Manonmaniam Sundaranar University, Rajakkamangalam-629 502, Kanyakumari DistrictTamil Nadu, India

Full list of author information is available at the end of the article
}

having significant proteolytic activity and stability at considerably higher $\mathrm{pH}$ and temperatures (Jacobs 1995; Yang et al. 2000).

The leather processing industry contributes significantly to the country's economic development. Waste from the leather industry leads to environmental pollution. Alkaline proteases have dehairing properties and can be used in the leather processing industry. Conventional methods in leather processing involve the use of hydrogen sulphide and other chemicals which are pollutants. Thus, for environmental reasons, the enzymatic dehairing process has more advantages over the chemical dehairing process (Andersen 1998). Proteases are used during the soaking, dehairing and bating states of preparing skins and hides. Pancreatic proteases are used in the bating process and the use of microbial alkaline proteases are popular (Varela et al. 1997). Alkaline proteases swell hair roots and attack hair follicle proteins, resulting in the easy removal of hair. These enzymes have been widely studied and their production from Bacillus sp. has gained momentum; 
moreover, the high activity and stability of these enzymes at various temperature and $\mathrm{pH}$ ranges have also attracted the attention of researchers. Dehairing proteases have been characterized from various Bacillus sp., e.g. B. subtilis 11QDB32 (Varela et al. 1997), B. amyloliquefaciens (George et al. 1995), B. subtilis K2 (Hameed et al. 1996; Hameed et al. 1999) and B. circulans (Subba Rao et al. 2009).

Proteases are generally produced using submerged fermentation not only due to its apparent advantages in consistent enzyme production but also for its cost- for medium components. From an industrial point of view, it is estimated that around $30-40 \%$ of the production cost of industrial enzymes can be attributed to the cost of the growth medium (Joo et al. 2003). Solid-state fermentation (SSF) has gained importance in the production of microbial enzymes owing to several economic advantages over submerged fermentation. The advantages of SSF include lower manufacturing costs with increased production, less pre-processing energy and effluent generation, along with easy process management and better product recovery (Prakasham et al. 2006; Oliveira et al. 2006). There are several reports describing the use of agro-industrial residues for the production of alkaline protease (e.g. pigeon pea and Bacillus sp. JB-99 (Johnvesly et al. 2002); green gram husk and Bacillus sp. (Prakasham et al. 2006); Imperata cylindrical grass and potato peel and Bacillus subtilis (Mukherjee et al. 2008). Apart from these agroindustrial residues, increased attention has been paid in recent times to utilize other waste substances, e.g. feather meal, corn steep liquor (De Azeredo et al. 2006) and proteinaceous tannery solid waste, for the production of alkaline proteases (Ravindran et al. 2011). Even though cow dung is considered a waste, it contains essential nutrients (Misra et al. 2003); these include carbon, nitrogen, phosphorus, potassium, calcium, magnesium, sulphur, manganese, copper, zinc, chloride, boron, iron and molybdenum.

Most of the commercial proteases producing organisms are Bacillus sp. (Abo-Aba et al. 2006). The potential of cow dung as a biomass substrate for the production of alkaline protease by using Bacillus sp. has not yet been completely exploited. The main objective of the present study was the production of alkaline proteases by Bacillus subtilis utilizing cow dung as an energy source, and determination of the optimum conditions necessary for the production of these enzymes.

\section{Results and discussion}

Isolation and identification of a best alkaline proteaseproducing organism

Of the tested isolates, five were found to have the ability to produce alkaline protease. Among the positive isolates, the organism which produced a larger halo zone in response to the colony diameter was selected. The selected isolate was identified as Bacillus on the basis of various microscopic and biochemical investigations. The organism was a Gram-positive rod, spore-producing, VP-, catalaseand gelatin-positive. It fermented glucose, lactose and sucrose. It reacted negatively in the indole, methyl red, citrate, oxidase, starch and nitrate reduction test. All these results suggest that it belongs to the genus Bacillus. Moreover, the organism was confirmed by its $16 \mathrm{~S}$ rRNA gene sequence and identified as Bacillus subtilis strain VV. The 1071-bp sequence was submitted to GenBank (accession number: JQ 425476).

\section{Evaluation of cow dung as a cheap substrate for alkaline protease production}

This study has indicated that cow dung can be used as a potential substrate for alkaline protease production. Enzyme production by the $B$. subtilis strain $\mathrm{VV}$ was to the tune of $4030 \pm 128 \mathrm{U} / \mathrm{g}$ solid substrate (cow dung) after $72 \mathrm{~h}$ of incubation at $37^{\circ} \mathrm{C}$. The selection of a cheap substrate in SSF for the production of any metabolites is an important factor from an industrial point of view. Apart from the cost, the availability of the substrate is a critical factor. An ideal substrate is one which is available in large quantities and throughout the year too. Although many cheap agro-industrial residues were evaluated (Prakasham et al. 2006; Johnvesly et al. 2002; Gessesse 1997) for the production of alkaline proteases, the availability of these substrates is seasonal. Apart from agro-industrial wastes, more attention has been paid to the evaluation of solid wastes for the production of alkaline proteases (Ravindran et al. 2011; Ganesh Kumar et al. 2008). Waste water from the manufacture of shochu was also tried (Morimura et al. 1994) for production of proteases. In spite of evaluating these substrates, the search for a novel substrate continues. Recently, we used cow dung as a substrate for the production of a halo-tolerant alkaline protease using a alkalophilic isolate, Halomonas sp. PV1 (Vijayaraghavan and Vincent 2012). Of all the alkalophilic microorganisms that have been screened for use in various industrial applications, members of the genus Bacillus were found to be predominant and a prolific source of alkaline proteases (Kumar and Takagi 1999). Reports on SSF of cow dung for the production of alkaline protease using Bacillus sp. are limited or perhaps not available. Hence, the present investigation aimed to exploit cow dung that is cheap and globally available for alkaline protease production by Bacillus subtilis. The protein content of the cow dung medium was evaluated before and after fermentation. The cow dung possessed $80 \pm 12 \mathrm{mg}$ protein/g solid substrate, and the organism utilized $40 \pm 4.5 \%$ of the protein content for the growth and synthesis of protease.

\section{Effect of fermentation period and $\mathrm{pH}$ on alkaline protease production}

To evaluate the effect of fermentation period on protease production, the fermentation experiment was carried 
out for a period of $96 \mathrm{~h}$. Results of this study showed that protease production increased with incubation time and was positively correlated $(\mathrm{r}=0.842)$. Maximum alkaline protease production was achieved after $72 \mathrm{~h}$ of fermentation $\left(4142 \pm 172 \mathrm{U} / \mathrm{g}\right.$ substrate) at $37^{\circ} \mathrm{C}$ (Figure 1a). The incubation time is governed by the characteristics of the culture and is also based on the growth rate and enzyme production. Similar findings have been reported with other Bacillus sp. (Ravindran et al. 2011). The reduction in enzyme yield after the optimum period was probably due to the depletion of nutrients available to the microorganisms. Here, enzyme production gradually decreased after $72 \mathrm{~h}$. The effect of $\mathrm{pH}$ on enzyme production was studied by culturing the organism at various $\mathrm{pH}$ levels (6.0-11.0). Enzyme production was $1502 \pm 120$, $2261 \pm 142,2945 \pm 110$ and $2291 \pm 153 \mathrm{U} / \mathrm{g}$ substrate at pH 6.0, 7.0, 8.0 and 9.0, respectively. Enzyme synthesis increased with increase in medium $\mathrm{pH}(\mathrm{r}=0.839)$, and maximum enzyme production was achieved at $\mathrm{pH} 10.0$ (4322 $\pm 148 \mathrm{U} / \mathrm{g}$ substrate). This trend clearly implies that this protease producer is alkaliphilic in nature. Enzyme production decreased at $\mathrm{pH} 11$ (3229 $\pm 129 \mathrm{U} / \mathrm{g}$ substrate). At higher $\mathrm{pH}$ level (11), protease production decreased as the metabolic action of the bacterium may be suppressed. This result was in accordance with the observations made with other alkaliphilic protease-secreting Bacillus sp. (Uyar and Baysal 2004). Alkaline protease production by microbial strains strongly depends on extracellular $\mathrm{pH}$ because culture $\mathrm{pH}$ strongly influences many enzymatic processes and transport of various components across the cell membranes, which in turn support cell growth and product production (Ellaiah et al. 2002).

\section{Influence of moisture content and inoculum on alkaline protease production}

The maximum enzyme production was observed with $140 \%$ moisture content $(5424 \pm 116 \mathrm{U} / \mathrm{g}$ substrate). The moisture content positively regulated enzyme production $(\mathrm{r}=0.763)$. The enzyme production decreased thereafter and it was $3722 \pm 102 \mathrm{U} / \mathrm{g}$ substrate at $180 \%$ moisture (Figure $1 \mathrm{~b}$ ). This could be attributed to low microbial growth and anchoring on the surface of the solid medium at higher moisture content. Among the several factors that are important for microbial growth and enzyme production under SSF, moisture content is a critical factor (Pandey et al. 2000; Nigam and Singh 1994). Cow dung has a high moisture-holding capacity. This could be the reason why the fermentation medium remained loose with higher moisture content and no free water. Even at a higher moisture level (180\%), the yield had not decreased much, revealing that this substrate supports the growth of the organism and production of proteases. There was a significant increase in alkaline protease production with an increase in
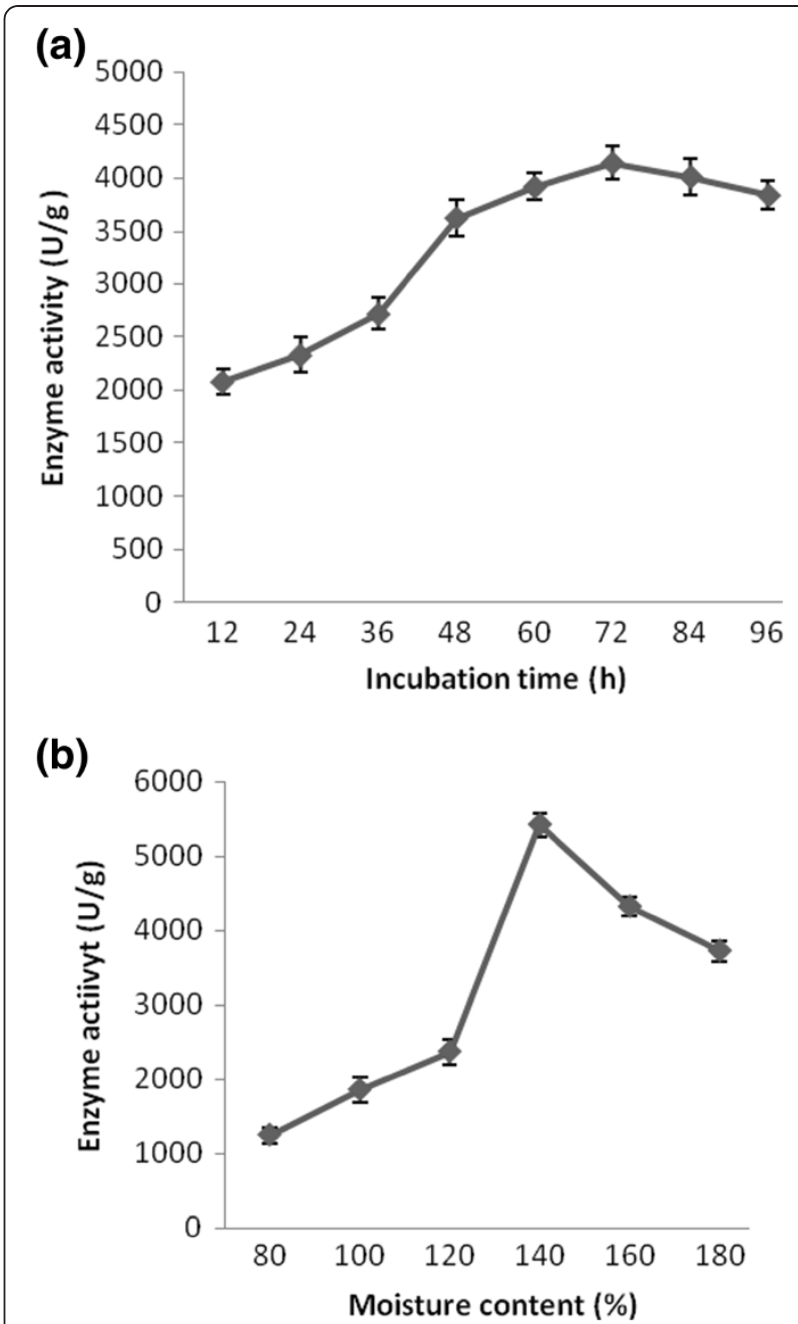

Figure 1 (a) Effect of fermentation period on enzyme production. The organism was grown in the cow dung substrate and incubated at $37^{\circ} \mathrm{C}$ for $72 \mathrm{~h}$. Error bar standard deviation. (b) Influence of initial moisture content on protease production by Bacillus subtilis strain W on cow-dung substrate. Error bar standard deviation.

inoculum size and the correlation coefficient $(r)$ was 0.931. Enzyme production was $609 \pm 42,2636 \pm 189$, $3879 \pm 201,4227 \pm 146,5626 \pm 197$ and $5094 \pm 132 \mathrm{U} / \mathrm{g}$ substrate at in inoculum sizes of $5 \%, 10 \%, 15 \%, 20 \%$, $25 \%$ and $30 \%$, respectively. Increase of the inoculum level after $25 \%$ adversely affected enzyme production. This result was in accordance the results observed with other Bacillus sp. (Rajkumar et al. 2011).

\section{Effect of temperature}

The effect of temperature on enzyme production was studied by culturing the organism at various temperatures $\left(10-50^{\circ} \mathrm{C}\right)$ and the enzyme production was not significantly increased. Enzyme production was $103 \pm 27,2527$ $\pm 91,3281 \pm 127,4617 \pm 101,5630 \pm 162 \mathrm{U} / g$ substrate at 
temperatures of $10,15,20,25$ and $30^{\circ} \mathrm{C}$, respectively. The optimum temperature for maximum protease production of $5842 \pm 108 \mathrm{U} / \mathrm{g}$ substrate in SSF was recorded as $35^{\circ} \mathrm{C}$. Incubation of temperatures below $35^{\circ} \mathrm{C}$ and above $40^{\circ} \mathrm{C}$ greatly reduced enzyme production. Enzyme production was recorded as $4015 \pm 87,2308 \pm 133$ and $1134 \pm 104$ $\mathrm{U} / \mathrm{g}$ solid substrate at 40,45 and $50^{\circ} \mathrm{C}$, respectively. Incubation temperature is one of the most critical parameters that have to be controlled in the bioprocess as culture temperature influences protease production by microorganism (Ghorbel et al. 2003).

\section{Evaluation of supplementation of carbon and nitrogen sources}

The solid medium was supplemented with several carbon sources such as glucose, lactose, trehalose, maltose, xylose and starch at $1 \%(\mathrm{w} / \mathrm{w})$ level. Among these, the addition of maltose and starch supported maximum production of protease with $5482 \pm 118 \mathrm{U} / \mathrm{g}$, and $4360 \pm 127$ U/g solid substrate respectively. Enzyme production was $2768 \pm 82,4076 \pm 103,3642 \pm 121$ and $4074 \pm 167 \mathrm{U} / \mathrm{g}$ substrate when glucose, lactose, xylose and trehalose were added, respectively. When different concentrations of maltose were added, maltose at $2 \%$ supported the maximum production with $5629 \pm 120 \mathrm{U} / \mathrm{g}$ substrate which was statistically significant $(r=0.737)$. In SSF, addition of carbon sources increases enzyme production. However, addition of the carbon source in the cow dung substrate increased the total enzyme yield by a mere $18 \%$. This clearly implies that cow dung contains more or less enough energy sources for the growth of microorganisms and protease production. The addition of maltose and starch enhanced protease production, with an increase of 30\% and 5\%, respectively. These results are in accordance with those of another study in which different sugars were supplemented (Ellaiah et al. 2002).

Among nitrogen sources, addition of urea supported maximum protease production ( $5412 \pm 142 \mathrm{U} / \mathrm{g}$ substrate). Addition of other sources such as gelatin $(3827 \pm 161 \mathrm{U} / \mathrm{g})$, peptone $(3485 \pm 128 \mathrm{U} / \mathrm{g})$, yeast extract $(3587 \pm 153 \mathrm{U} / \mathrm{g})$ and casein $(4830 \pm 134 \mathrm{U} / \mathrm{g})$ also supported protease production. Ammonium chloride repressed protease production $(2787 \pm 64 \mathrm{U} / \mathrm{g})$. When different concentrations of urea were added, urea at $1 \%$ supported maximum protease production with $5489 \pm 142 \mathrm{U} / \mathrm{g}$. Enzyme production was not significantly increased in other concentrations and was not statistically significant. Results presented in Figure 2 show the influence of adding maltose, urea and their combinations on alkaline protease production under SSF at varying incubation times.

\section{Purification of the protease and SDS-PAGE}

The alkaline protease of the crude extract was purified for homogeneity by a two-step procedure: ammonium sulphate precipitation and Sephadex G-75 gel filtration. In crude extract the specific activity was $16.11 \mathrm{U} / \mathrm{mg}$ protein, with an yield of $100 \%$. The alkaline protease was purified 2.45 fold with ammonium sulphate precipitation and further chromatographic separation in Sephadex G-75 column to obtain an $18.37 \%$ yield. The specific activity of the purified enzyme was $152.61 \mathrm{U} / \mathrm{mg}$ protein. A typical purification experiment is summarized in Table 1. In the SDSPAGE, the purified enzyme migrated as a single band with an apparent molecular weight of $38.5 \mathrm{kDa}$ (Figure 3a); this was also the case with the zymography analysis (Figure $3 \mathrm{~b}$ ). These results are in accordance with literature reports where molecular masses of most proteases derived from Bacillus sp. are less than $50 \mathrm{kDa}$ (Sousa et al. 2007).

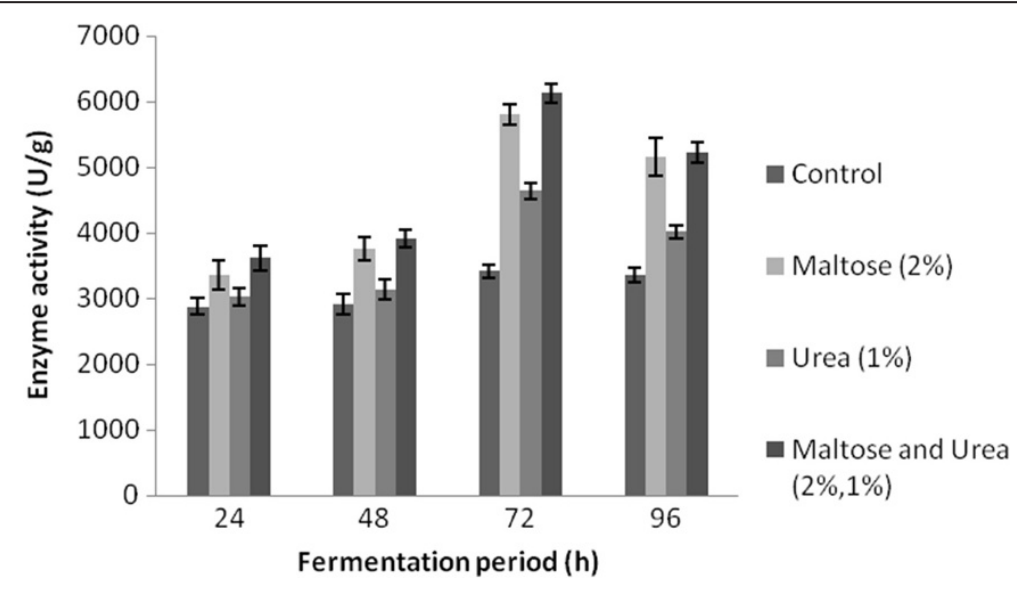

Figure 2 Effect of maltose, urea, and their combination influence on alkaline protease production by Bacillus subtilis strain VV under solid-state fermentation with cow dung. Error bar standard deviation. 


\section{Effect of temperature and $\mathrm{pH}$ on the activity of alkaline protease}

Enzyme activity was increased with increase in temperature and was statistically significant $(\mathrm{p}<0.05)$. At around $50^{\circ} \mathrm{C}$, the maximum protease activity (5922 \pm 182 $\mathrm{U} / \mathrm{g}$ ) was determined and it declined at higher temperatures. The enzyme activity was $3062 \pm 123,4432 \pm 138$, $3802 \pm 107$, and $994 \pm 42 \mathrm{U} / \mathrm{g}$ at $30,40,60$ and $70^{\circ} \mathrm{C}$, respectively. Enzyme activity was not detected at $80^{\circ} \mathrm{C}$. This might be due to the total denaturation of the enzyme. This protease could be classified as thermostable, because of its optimal activity at $50^{\circ} \mathrm{C}$. This result was in accordance with the results obtained with other Bacillus sp. (Rajkumar et al. 2011). When analyzed for thermal stability, the protease was found to be stable for $40 \mathrm{~min}$ at $50^{\circ} \mathrm{C}$ $(42 \pm 3.8 \%$ activity), which decreased to $2 \pm 0.13 \%$ after $120 \mathrm{~min}$ of denaturation at this temperature. The effect of $\mathrm{pH}$ on enzyme activity was evaluated in the $\mathrm{pH}$ range, 6.0 to 11.0 and optimal activity occurred in the alkaline range ( $\mathrm{pH}$ 9.0-11.0). The enzyme produced by the Bacillus subtilis strain VV revealed robustness towards alkaline $\mathrm{pH}$. Enzyme activity was found to be the high at higher $\mathrm{pH}(10.0)$ (7464 $\pm 169 \mathrm{U} / \mathrm{g}$ material) and was statistically significant $(\mathrm{p}<0.05)$. The enzyme activity was $1156 \pm 72,3548 \pm 112$, $3631 \pm 147,4140 \pm 118$ and $4744 \pm 152$ for the $\mathrm{pH}$ 6.0, 7.0, 8.0, 9.0 and 11.0, respectively. This result was in accordance observations made with other Bacillus sp. (Ghorbel et al. 2003; Arulmani et al. 2007). The protease was stable over a $\mathrm{pH}$ range of 8.0 to 11.0 , and was highly stable at $\mathrm{pH}$ 9.0 (100\% relative activity). It lost approximately $15.7 \pm$ $1.8 \%$ and $33.7 \pm 2.6 \%$ activity at $\mathrm{pH} 10.0$ and 11.0 , respectively. However, more than $61 \pm 4.1 \%$ of the enzyme activity was lost when the $\mathrm{pH}$ fell below 6.0. Similar pattern of $\mathrm{pH}$ stability of protease produced by Bacillus circulans was described earlier (Towatana et al. 1999).

\section{Effect of ions on enzyme activity}

The effect of various divalent ions $(0.01 \mathrm{M})$ on the activity of the enzyme was evaluated. Of the various divalent ions added, $\mathrm{Ca}^{2+}$ ions were found to increase enzyme activity $(108 \pm 4.9 \%)$. This result was in accordance with results observed with other Bacillus sp. in a similar study (Towatana et al. 1999). Ions like $\mathrm{Cu}^{2+}(64 \pm 2.8 \%), \mathrm{Fe}^{2+}$ $(73 \pm 5.3 \%), \mathrm{Hg}^{2+}(13.2 \pm 1.6 \%)$ and $\mathrm{Zn}^{2+}(61.9 \pm 3.4 \%)$ strongly inhibited enzyme activity. Enzyme activity was slightly affected by $\mathrm{Mg}^{2+}$ and $\mathrm{Mn}^{2+}$ ions. The characteristic features of the enzyme produced by $B$. subtilis in this study were similar to that produced by Bacillus circulans (Subba Rao et al. 2009).

\section{Effect of organic solvent, surfactants and detergents on the stability of protease}

The enzyme was stable towards all tested organic solvent (1\%) for $1 \mathrm{~h}$ at room temperature. Among the organic solvents tested, methanol and acetonitrile showed better stability (Table 2) but these were not significantly increased. The alkaline protease was stable towards the non-ionic surfactants like SDS, tween-20, tween-80 and triton X-100 and the enzyme activity was $104 \pm 2.1 \%$, $168.2 \pm 7.8 \%, 111.5 \pm 9.8 \%$ and $141.3 \pm 21 \%$, respectively. These results were statistically significant $(\mathrm{p}<0.05)$. This finding gains significance because modern bleach-based detergent formulations are mainly composed of SDS. This result is in accordance with the observation made with Bacillus clausii (Joo et al. 2003). This enzyme showed significant stability $(\mathrm{p}<0.05)$ in the presence of commercially available detergent such as Sunlight and Ujala after $1 \mathrm{~h}$ of incubation. This alkaline protease was evaluated for its possible applications in detergent formulation as it showed stability after $1 \mathrm{~h}$ and $24 \mathrm{~h}$ incubation with these detergents and the results are presented in Table 2. A similar result was reported with Bacillus circulans (Subba Rao et al. 2009). The enzymatic properties of the protease suggest its suitability as an addition to detergent formulations.

\section{Dehairing of skin}

In the present study, $4.0 \mathrm{mg}$ enzyme solution effectively removed hair from the goat skin after $16 \mathrm{~h}$ of incubation at room temperature $\left(30^{\circ} \mathrm{C}\right)$ (Figure 4$)$. This enzyme has non-keratinolytic and non-collagenolytic in nature. Several microbial proteases were evaluated for their dehairing property (Sivasubramanian et al. 2008; Aravindan et al. 2007) and it was noticed that only those enzymes with stability under alkaline conditions especially between 9.0 and 11.0 are important. Bacillus subtilis proteases had many advantages when compared with proteases from other Bacillus sp. because of its stability at this range. There is not much published literature concerning enzymatic dehairing process. It is gaining importance as an alternative chemical process and is significant in the reduction of toxicity in addition to the improvement of the texture of leather (Sivsubramanian et al. 2008). Alkaline proteases derived from B. circulans, B. cereus and B. subtilis dehaired

Table 1 Purification summary of extracellular alkaline protease from Bacillus subtilis strain VV

\begin{tabular}{llllll}
\hline Purification Step & Total activity (U) & Total protein (mg) & Specific activity (U/mg) & Yield (\%) & Purification (fold) \\
\hline Crude enzyme & 16200 & 1005 & 16.11 & 1 & 100 \\
\hline Ammonium sulphate & 9740 & 246 & 39.59 & 60.12 & 2.45 \\
\hline Sephadex G-75 & 2976 & 19.5 & 152.61 & 18.37 & 9.47 \\
\hline
\end{tabular}




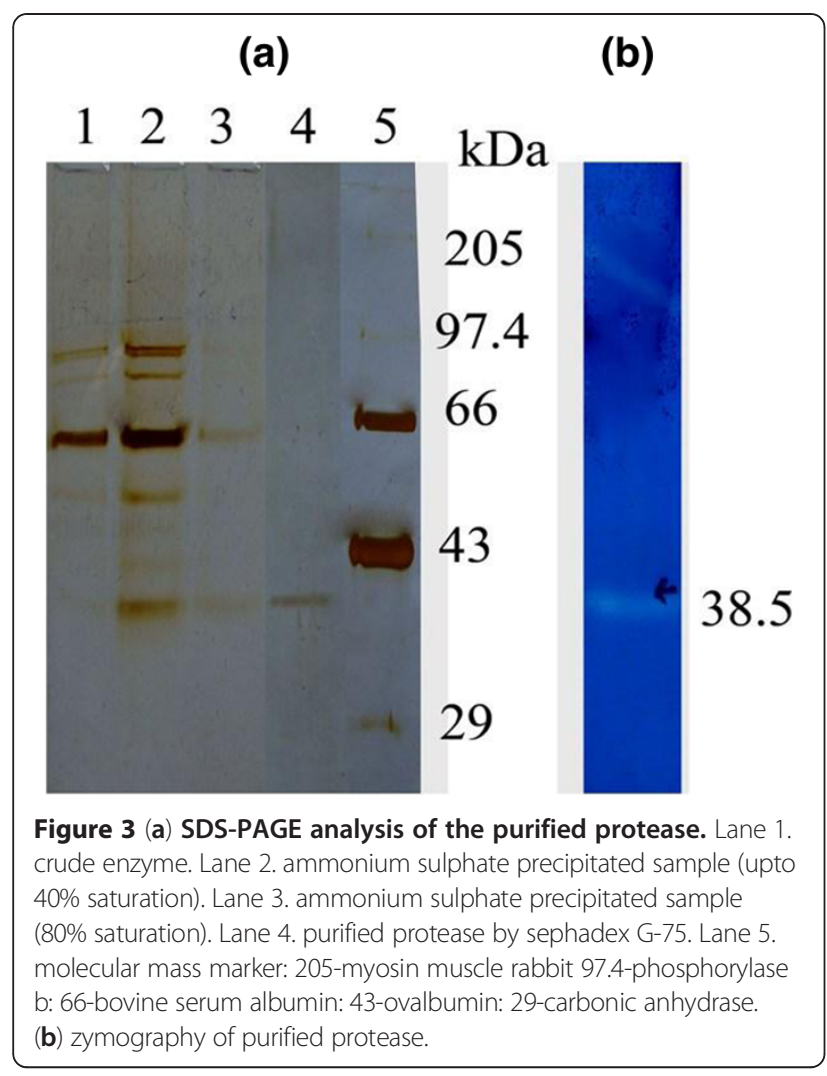

the goat skin in 18, 21 and $12 \mathrm{~h}$, respectively (Subba Rao et al. 2009; Sivasubramanian et al. 2008; Nilegaonkar et al. 2007). Based on this fact, alkaline protease derived from B. subtilis strain VV can find great use in the leather processing industry.

Table 2 Effect of solvent and detergents on protease activity from Bacillus subtilis strain VV

\begin{tabular}{lllll}
\hline \multicolumn{2}{l}{$\begin{array}{l}\text { Effect of solvent } \\
\text { Solvent }\end{array}$} & $\begin{array}{l}\text { Residual } \\
\text { activity } \\
\text { (\%) }\end{array}$ & $\begin{array}{l}\text { Detergent } \\
\mathbf{( 1 \% )}\end{array}$ & \multicolumn{2}{l}{ Relative activity (\%) } \\
\cline { 4 - 5 } & $\mathbf{a f t e r} \mathbf{1} \mathbf{~}$ & after 24 $\mathbf{~}$ \\
\hline n-Butanol & $66.3 \pm 4$ & Sun light & $113 \pm 7$ & $50 \pm 4$ \\
\hline Toluene & $77.2 \pm 4$ & mr. White & $84 \pm 5$ & $14 \pm 1$ \\
\hline Methanol & $102.2 \pm 3$ & Henko & $99 \pm 4$ & $30 \pm 5$ \\
\hline Acetone & $80.5 \pm 3$ & Ujala & $110 \pm 5$ & $19 \pm 3$ \\
\hline Acetonitrile & $99.2 \pm 8$ & Tide+ & $85 \pm 6$ & $81 \pm 5$ \\
\hline Benzene & $82.6 \pm 6$ & Surf excel & $93 \pm 5$ & $31 \pm 4$ \\
\hline Ethanol & $92.5 \pm 6$ & Aircel & $13 \pm 2$ & 0 \\
\hline
\end{tabular}

The protease was pre-incubated with solvent and surfactants at predetermined time and the remaining activity was measured using the standard protease assay. Residual and relative enzyme activity was determined as percentage of control with no additions.

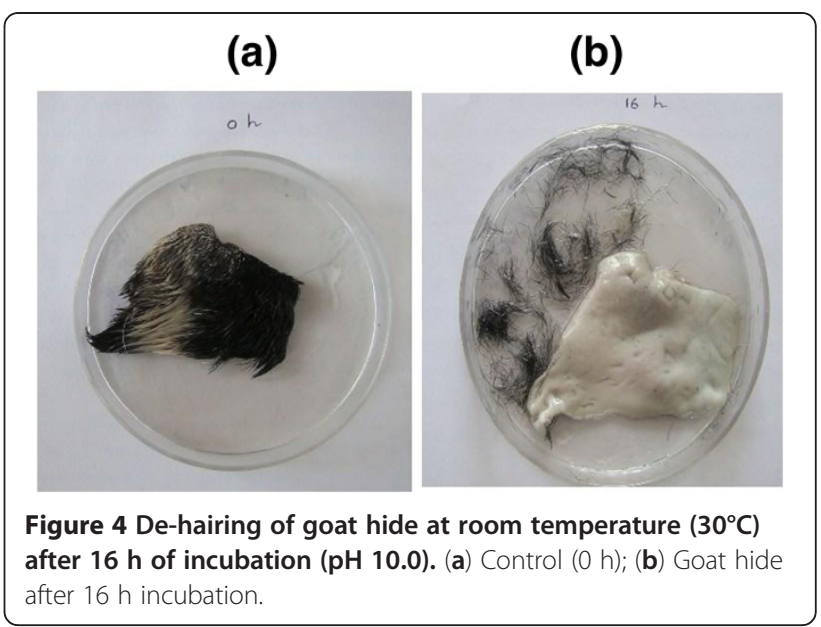

\section{Methods}

Isolation of proteolytic microorganisms

Eleven alkaliphilic bacteria were isolated from soil sediments from a small river (Pantivaikal Odai, Pampanvilai, Nagercoil, Kanyakumari District, India). The soil sample collected was found to be highly alkaline due to the extensive use of soap and detergents for cleaning clothes in the river by the local population. All of the isolates were cultured on skimmed milk agar plates (in $\mathrm{g} \mathrm{l}^{-1}$ : [peptone-5; yeast extract-5; $\mathrm{KH}_{2} \mathrm{PO}_{4}-1.0 ; \mathrm{MgSO}_{4}-0.2$; skimmed milk10; NaCl-10; agar-15; $\mathrm{pH} 10.0]$ ). The isolate having the highest ratio of clear zone diameter $(\mathrm{mm})$ to colony diameter $(\mathrm{mm})$ was selected to test their ability to produce alkaline protease.

\section{Identification of the potential isolate}

Bacterial identification was conducted based on morphological and biochemical tests (Mac Faddin 2000). Morphological and physiological characteristics of the isolated bacterium were verified by using 'Bergey's Manual of Systematic Bacteriology' (Jones and Collins 1984). The 16S rRNA gene was sequenced after genomic DNA extraction and PCR amplification as described elsewhere (Riffel et al. 2003).

\section{Solid-state fermentation and protease extraction}

Cow dung was obtained from a farm house and dried for several days. It was powdered using a mixer grinder, sieved and stored in airtight containers before further use. Five grams of the substrate (cow dung) was taken in a 250-mL Erlenmeyer flask and the moisture content was maintained as $100 \%$ using glycine- $\mathrm{NaOH}$ buffer $(\mathrm{pH}$ 10.0, $0.1 \mathrm{M}$ ). The contents were mixed thoroughly and autoclaved at $121^{\circ} \mathrm{C}$ for $15 \mathrm{~min}$. After cooling the flask to room temperature, it was inoculated with $0.5 \mathrm{~mL}$ of 24-h grown $\left(\mathrm{OD}_{600 \mathrm{~nm}}=0.917\right)$ culture broth under sterile conditions. The culture was then incubated for $72 \mathrm{~h}$ at $37^{\circ} \mathrm{C}$, and after incubation, $50 \mathrm{~mL}$ of double distilled water 
was added to the fermented substrate. This was placed in an orbital shaker at $150 \mathrm{rpm}$ for $30 \mathrm{~min}$ for enzyme extraction. After this, the mixture was rapidly filtered using cotton and the cells were further harvested by centrifugation at $10,000 \mathrm{~g}$ for $20 \mathrm{~min}$. The supernatant was used as the enzyme source for protease assay.

\section{Determination of protease activity}

Alkaline protease activity was determined by standard assay. The reaction mixture contained $5 \mathrm{~mL}$ of casein (prepared in $0.05 \mathrm{M}$ of glycine- $\mathrm{NaOH}$ buffer, $\mathrm{pH}$ 10.0) and an aliquot of $0.1 \mathrm{~mL}$ of the enzyme solution, and this mixture was incubated for $30 \mathrm{~min}$ at $37^{\circ} \mathrm{C}$. The reaction was stopped by adding $5 \mathrm{~mL}$ of trichloroacetic acid solution (TCA) $(0.11 \mathrm{M})$ and the mixture was filtered after $30 \mathrm{~min}$. To $2 \mathrm{~mL}$ of the filtrate, $5.0 \mathrm{~mL}$ of $0.5 \mathrm{M}$ sodium carbonate and $1.0 \mathrm{~mL}$ of Folin-Ciocalteu's phenol reagent were added, and this mixture was kept undisturbed for $30 \mathrm{~min}$ at $37^{\circ} \mathrm{C}$. The optical density of the solution was read against sample blank at $630 \mathrm{~nm}$. One unit of enzyme activity was defined as the amount of enzyme required to liberate $1 \mu \mathrm{g}$ of tyrosine per minute under assay conditions (Chopra and Mathur 1985). The total protein content was estimated by Bradford's method (Bradford 1976).

\section{Optimization of process parameters for protease production}

In the present study, solid-state protease production by the Bacillus subtilis strain VV was optimized by varying the physical parameters and nutrient sources. The protease activity was determined in the fermented medium for every $12 \mathrm{~h}$ of fermentation up to $96 \mathrm{~h}$ in order to determine the fermentation period. To evaluate the effect of temperature on protease production, the substrate inoculated with bacterial culture was incubated at various temperatures $\left(10-50^{\circ} \mathrm{C}\right)$. Addition of buffer $(0.1 \mathrm{M})$ was performed so that the $\mathrm{pH}$ of the solid medium was varied from $\mathrm{pH} 6.0$ to 11.0. To study the effect of the initial moisture content on protease production, the initial moisture content of the cow dung was adjusted to $60-180 \%$ using glycine- $\mathrm{NaOH}$ buffer ( $\mathrm{pH}$ 10.0). To determine the effect of inoculum size on protease production, the inoculum concentration was increased accordingly (5-30\%).

In addition to the physical parameters, nutrient parameters were also optimized. This included the effect of carbon sources $(1 \%, \mathrm{w} / \mathrm{w})$ (glucose, lactose, trehalose, maltose, xylose and starch) and nitrogen sources $(1 \%, \mathrm{w} / \mathrm{w})$ (gelatin, ammonium nitrate, peptone, yeast extract, urea, skimmed milk, and casein). The maximum production of protease at various concentrations $(0.5-2.5 \%)$ of maltose as a carbon source and urea as a nitrogen source was investigated. The effect of the optimum concentration of maltose, urea and their combination on alkaline protease production for 24-96 h was also evaluated. The results reported in this study are averages of triplicate findings.

\section{Purification of protease}

The organism was grown aerobically in an optimized medium for $72 \mathrm{~h}$ at $37^{\circ} \mathrm{C}$ and extracted as described in materials and method section. Samples were centrifuged at $10,000 \mathrm{~g}$ for $10 \mathrm{~min}$, and the supernatant was used as a crude enzyme preparation. It was precipitated with ammonium sulphate $(40-80 \%$ saturation) and the enzyme precipitate obtained was centrifuged at $10,000 \mathrm{~g}$ for $10 \mathrm{~min}$ at $4^{\circ} \mathrm{C}$. The precipitate obtained from the previous step was re-suspended in $5.0 \mathrm{~mL}$ of $0.025 \mathrm{M}$ Tris- $\mathrm{HCl}$ buffer and dialysed against the same buffer. The dialysed sample was applied to a Sephadex G-75 gel filtration column $(0.6 \times 45 \mathrm{~cm})$, and eluted with $0.025 \mathrm{M}$ Tris- $\mathrm{HCl}$ buffer at $\mathrm{pH} 8.0$, at a flow rate of $0.5 \mathrm{~mL} / \mathrm{min}$. Fractions of $2.0 \mathrm{~mL}$ were collected and the optical density of the sample was measured at $280 \mathrm{~nm}$ and analysed for proteolytic activity.

\section{SDS-PAGE and zymography}

Sodium dodecyl sulphate-polyacrylamide gel electrophoresis was carried out according to (Laemmli 1970) using $11 \%$ crosslinked polyacrylamide gel. Silver staining was performed to visualize protein bands. Zymographic analysis was performed by the enzyme pattern of proteins, obtained by zymogram with $1 \%$ casein substrate and detected using coomassie brilliant blue R-250 (Westergaar et al. 1980).

\section{Characterization of protease activity}

The effect of $\mathrm{pH}$ on the activity of the enzyme was studied by assaying the enzyme activity at different $\mathrm{pH}$ values ranging from 5.0 to11.0. To check the stability of the enzyme at various $\mathrm{pH}, 100 \mu \mathrm{L}$ of the enzyme solution was mixed with $900 \mu \mathrm{L}$ of buffer solutions (pH 5.0-11.0) and the mixture was taken to measure the protease activity under standard assay conditions after incubation for $1 \mathrm{~h}$. The effect of temperature on enzyme activity was studied by holding the reactions at various temperatures $\left(30-70^{\circ} \mathrm{C}\right)$ using the standard assay method. To evaluate the heat stability of the protease, the sample was denatured at an optimized temperature $\left(50^{\circ} \mathrm{C}\right)$ for $0-120 \mathrm{~min}$. To study the effect of ions $(0.01 \mathrm{M})$ on enzyme activity, the sample was pre-incubated with various divalent ions at $37^{\circ} \mathrm{C}$ for $1 \mathrm{~h}$ and the activity evaluated. To examine the effect of solvents, surfactants and detergents on enzyme activity, many agents were added to the enzyme solution at the indicated concentration, allowed to stand for $1 \mathrm{~h}$ and $24 \mathrm{~h}$ at room temperature and the activity measured. To evaluate the dehairing property of an enzyme, fresh goat-hide 
was incubated with $4.0 \mathrm{mg}$ enzyme solution ( $\mathrm{pH}$ 10.0) for up to $16 \mathrm{~h}$ at room temperature.

\section{Statistical analysis}

All experiments were performed in triplicate. Data were analyzed by correlation coefficient ( $\mathrm{r}$ ) and Student's ' $\mathrm{t}$ ' test. A significance level of 0.05 or less was considered statistically significant.

\section{Conclusions}

In conclusion, cow dung was utilized as a substrate for the production of alkaline protease in SSF. Cow dung is a cheaply available bioresource and this substrate is available in almost every country. So, this biomass could be effectively utilized for the production of alkaline protease an industrial scale. Apart from the significance of the substrate, the enzyme secreted by $B$. subtilis strain VV is useful in the detergent and leather-processing industries.

\section{Competing interests}

The authors declare that they have no competing interests.

\section{Authors' contribution}

$\mathrm{PV}$ designed and executed this project work. AV, AA and JJ gave technical assistance. SGPV guided this project work. All the authors have approved the submission of the manuscript.

\section{Acknowledgements}

One of the authors, P. Vijayaraghavan is thankful to the Council of Scientific and Industrial Research, New Delhi, India for financial support in the form of a Senior Research Fellowship.

\section{Author details}

${ }^{1}$ International Centre for Nanobiotechnology, Centre for Marine Science and Technology, Manonmaniam Sundaranar University, Rajakkamangalam-629 502, Kanyakumari DistrictTamil Nadu, India. ${ }^{2}$ Centre for Marine Science and Technology, Manonmaniam Sundaranar University, Rajakkamangalam-629 502, Kanyakumari District, Tamil Nadu, India. ${ }^{3}$ Department of Biotechnology, Kalasalingam University, Virudhunagar, Srivilliputtur, 626 126, Tamilnadu, India.

Received: 5 October 2012 Accepted: 19 December 2012 Published: 22 December 2012

\section{References}

Abo-Aba SEM, Soliman EAM, Nivien AA (2006) Enhanced production of extra cellular alkaline protease in Bacillus ciculance through plasmid transfer. Res J Agric Biol Sci 16:526-530

Andersen LP (1998) Method for dehairing of hides or skins by means of enzymes. US Patent 5:834,299

Aravindan R, Saravanabhavan S, Thanikaivelan P, Rao JR, Nair BUA (2007) Chemo enzymatic pathway leads towards zero discharge tanning. J Clean Product 15:1217-1227

Arulmani M, Aparanjini K, Vasanthi K, Arumugam A, Arivuchelvi M, Thangavelu Kalaichelvan PT (2007) Purification and partial characterization of serine protease from thermostable alkalophilic Bacillus laterosporus -AK1. World J Microbiol Biotechnol 23(4):475-481

Bradford MM (1976) A rapid and sensitive method for the quantization of microgram quantities of protein utilizing the principle of protein-dye binding. Anal Biochem 72:248-254

Chopra AK, Mathur DK (1985) Purification and characterization of heat-stable protease from Bacillus stearothermophilus RM-67. J Dairy Sci 68:3202-3211

De Azeredo LA, De Lima MB, Coelho RR, Freire DM (2006) A low-cost fermentation medium for thermophilic protease production by Streptomyces sp. 594 using feather meal and corn steep liquor. Curr Microbiol 53(4):335-339

Ellaiah P, Srinivasulu B, Adinarayana K (2002) A review on microbial alkaline proteases. J Sci Ind Res 61:690-704

Ganesh Kumar A, Nagesh N, Prabhakar TG, Sekaran G (2008) Purification of extracellular acid protease and analysis of fermentation metabolities by Synergistes sp. utilizing proteinaceous solid waste from tanneries. Bioresour Technol 99:2364-2372

Gessesse A (1997) The use of nug meal as a low-cost substrate for the production of alkaline protease by the alkaliphilic Bacillus sp. AR-009 and some properties of the enzyme. Bioresour Technol 62:59-61

George S, Raju V, Krishnan MRV, Subramanian TV, Jayaraman K (1995) Production. of protease by Bacillus amyloliquefaciens in solid-state fermentation ant its application in the unhairing of hides and skins. Process Biochem 30:457-462

Ghorbel B, Sellami-Kamoun A, Nasri M (2003) Stability studies of protease from Bacillus cereus BG1. Enzyme Microb Technol 32:513-518

Hameed A, Natt MA, Evans CS (1996) Production of alkaline protease by a new Bacillus subtilis isolate for use as a bating enzyme in leather treatment. World J Microbiol Biotechnol 12:289-291

Hameed A, Keshavarz T, Evans CS (1999) Effect of dissolved oxygen tension and $\mathrm{pH}$ on the production of extracellular protease from a new Bacillus subtilis K2, for use in leather processing. J Chem Technol Biotechnol 74:5-8

Jacobs MF (1995) Expression of the subtilisin Carlsberg-encoding gene in Bacillus licheniformis and Bacillus subtilis. Gene 152:67-74

Johnvesly B, Manjunath BR, Naik GR (2002) Pigeon pea waste as a novel, inexpensive, substrate for production of a thermostable alkaline protease from thermoalkalophilic Bacillus sp. JB-99. Bioresour Technol 82:61-64

Jones D, Collins MD (1984) Irregular, nonsporeforming Gram-positive rods. In: Sneath PHA (ed) Bergey's Manual of systematic bacteriology, Vol. 2. Williams and Wilkins, Baltimore, MD, pp 1261-1434

Joo HS, Kumar CG, Park GC, Paik SR, Chang CS (2003) Oxidant and SDS-stable alkaline protease from Bacillus Clausii I-52: production and some properties. J Appl Microbiol 95:267-272

Kumar CG, Takagi H (1999) Microbial alkaline proteases from a bioindustrial viewpoint. Biotechnol Adv 17:561-594

Laemmli UK (1970) Cleavage of structural proteins during the assembly of the head of bacteriophage T4. Nature 227(5259):680-685

MacFaddin JF (2000) Biochemical tests for identification of medical bacteria. Lippincott Williams and Wilkins, Baltimore, MD

Misra RV, Roy RH, Hiraoka (2003) On farm composting method. FAO, Rome

Morimura S, Kida K, Sonoda Y (1994) Production of protease using waste-water from the manufacture of shochu. J Ferment Bioeng 77(2):183-187

Mukherjee AK, Adhikari H, Rai SK (2008) Production of alkaline protease by a thermophilic Bacillus subtilis under solid-state fermentation (SSF) condition using Imperata cylindrical grass and potato peel as low cost medium: Characterization and application of enzyme in detergent formulation. Biochem Eng J 39:353-361

Nigam P, Singh D (1994) Solid state (substrate) fermentation system and their applications in biotechnology. J Basic Microbiol 34:405-423

Nilegaonkar SS, Zambare WP, Kanekar PP, Dhakephalkar PK, Sarnaik SS (2007) Production and partial characterization of dehairing protease from Bacillus cereus MCM B-326. Bioresour Technol 98:1238-1245

Oliveira LA, Porto ALF, Tambourgi EB (2006) Production of xylanase and protease by Penicillium janthinellum CRC $87 \mathrm{M}-115$ from different agricultural wastes. Bioresour Technol 98:1238-1245

Pandey A, Soccol CR, Nigam P, Brand D, Mohan R, Roussos S (2000) Biotechnological potential of coffee pulp and coffee husk for bioprocesses. Biochem Eng J 6:153-162

Prakasham RS, Subba Rao C, Sarma PN (2006) Green gram husk: an inexpensive substrate for alkaline protease production by Bacillus $\mathrm{sp}$. in solid-state fermentation. Bioresour Technol 97:1449-1454

Rajkumar R, Ranishee JK, Ramasamy R (2011) Production and characterizaion of a novel proteases from Bacillus sp. RRM1 under solid state fermentation. J Microbiol Biotechnol 21(6):627-636

Ravindran B, Ganesh Kumar A, Aruna Bhavani PS, Sekaran G (2011) Solid-state fermentation for the production of alkaline protease by Bacillus cereus 1173900 using proteinaceous tannery solid waste. Curr Sci 100(5):726-730

Riffel A, Ortolan S, Brandelli A (2003) De-hairing activity of extracellular proteases produced by keratinolytic bacteria. J Chem Technol Biotechnol 78:855-859 
Scheuer PJ (1990) Some marine ecological phenomena: chemical basis and biomedical potential. Science 248:173-177

Sivasubramanian S, Murali Manohar B, Rajaram A, Puvanakrishna R (2008) Ecofriendly lime and sulfide free enzymatic dehairing of skins and hides using a bacterial alkaline protease. Chemosphere 70:1015-1024

Sousa F, Ju S, Erbel A, Kokol V, Cavaco-Paulo A, Gubitz GM (2007) A nove metalloprotease from Bacillus cereus for protein fibre processing. Enzyme Microb Technol 40:1772-1781

Subba Rao C, Sathish T, Ravichandra P, Prakasham RS (2009) Characterization of thermo- and detergent stable serine protease from isolated Bacillus circulans and evaluation of eco-friendly applications. Process Biochem 44:262-268

Towatana NH, Painupong A, Suntinanalert P (1999) Purification and characterization of an extracellular protease from alkaliphilic and thermophilic Bacillus sp. PS7. J Biosci Bioeng 87:581-587

Uyar F, Baysal Z (2004) Production and optimization of process parameters for alkaline protease production by a newly isolated Bacillus sp. under solid state fermentation. Process Biochem 39(12):1893-1898

Varela H, Ferrari MD, Belobradjic L, Vazquez A, Loperena ML (1997) Skin unhairing proteases of Bacillus subtilis: production and partial characterization. Biotechnol Lett 19:755-758

Vijayaraghavan P, Vincent SGP (2012) Cow dung as a novel, inexpensive substrate for the production of a halo-tolerant alkaline protease by Halomonas sp. PV1 for eco-friendly applications. Biochem Eng J 69:57-60

Westergaar JL, Hackbarth C, Treuhaft MW, Roberts RC (1980) Detection of proteinases in electrophorograms of complex mixtures. J Immunol Meth 34(2):167-175

Yang JK, Shih IL, Tzeng YM, Wang SL (2000) Production and purification of protease from a Bacillus subtilis that can deproteinize crustacean wastes. Enzyme Microb Technol 26:406-413

doi:10.1186/2193-1801-1-76

Cite this article as: Vijayaraghavan et al.: Cow dung: a potential biomass substrate for the production of detergent-stable dehairing protease by alkaliphilic Bacillus subtilis strain VV. SpringerPlus 2012 1:76.

\section{Submit your manuscript to a SpringerOpen ${ }^{\circ}$ journal and benefit from:}

- Convenient online submission

- Rigorous peer review

- Immediate publication on acceptance

Open access: articles freely available online

- High visibility within the field

- Retaining the copyright to your article

Submit your next manuscript at $>$ springeropen.com 